\title{
DNA Electrochemical Biosensor Based on Iron Oxide/Nanocellulose Crystalline Composite Modified Screen-Printed Carbon Electrode for Detection of Mycobacterium tuberculosis
}

\author{
Mohd Hazani Mat Zaid 1,2 (D), Che Engku Noramalina Che-Engku-Chik ${ }^{3,4}$, Nor Azah Yusof 1,2, \\ Jaafar Abdullah ${ }^{1,2}{ }^{\mathbb{D}}$, Siti Sarah Othman ${ }^{5} \mathbb{D}$, Rahizan Issa ${ }^{6}$, Mohd Fairulnizal Md Noh ${ }^{7}$ and \\ Helmi Wasoh 3,4,8,* \\ 1 Department of Chemistry, Faculty of Science, Universiti Putra Malaysia, Serdang 43400, Malaysia; \\ zani@ukm.edu.my (M.H.M.Z.); azahy@upm.edu.my (N.A.Y.); jafar@upm.edu.my (J.A.) \\ 2 Department of chemical sciences, Faculty of Science and Technology, Universiti Kebangsaan Malaysia, \\ Bangi 43600, Malaysia \\ 3 Department of Bioprocess Technology, Faculty of Biotechnology and Biomolecular Sciences, \\ Universiti Putra Malaysia, Serdang 43400, Malaysia; engkuamalina@gmail.com \\ 4 Institute of Advanced Technology (ITMA), Universiti Putra Malaysia, Serdang 43400, Malaysia \\ 5 Department of Cell and Molecular Biology, Faculty of Biotechnology and Biomolecular Sciences, \\ Universiti Putra Malaysia, Serdang 43400, Malaysia; sarahothman@upm.edu.my \\ 6 Bacteriology Unit, Infectious Disease Research Centre, Institute for Medical Research, Jalan Pahang, \\ Kuala Lumpur 50588, Malaysia; rahizzan@imr.gov.my \\ 7 Cardiovascular Diabetes and Nutrition Research Centre, Institute for Medical Research, Jalan Pahang, \\ Kuala Lumpur 50588, Malaysia; fairul@imr.gov.my \\ 8 Halal Product Research Institute (IPPH), Universiti Putra Malaysia, Serdang 43400, Malaysia \\ * Correspondence: helmi_wmi@upm.edu.my
}

Academic Editors: Anna Borriello, Francesca Santoro and Vincenzo Guarino Received: 15 May 2020; Accepted: 3 June 2020; Published: 24 July 2020

\begin{abstract}
Death from tuberculosis has resulted in an increased need for early detection to prevent a tuberculosis (TB) epidemic, especially in closed and crowded populations. Herein, a sensitive electrochemical DNA biosensor based on functionalized iron oxide with mercaptopropionic acid (MPA- $\mathrm{Fe}_{3} \mathrm{O}_{4}$ ) nanoparticle and nanocellulose crystalline functionalized cetyl trimethyl ammonium bromide (NCC/CTAB) has been fabricated for the detection of Mycobacterium tuberculosis (MTB). In this study, a simple drop cast method was applied to deposit solution of $\mathrm{MPA}-\mathrm{Fe}_{3} \mathrm{O}_{4} / \mathrm{NCC} / \mathrm{CTAB}$ onto the surface of the screen-printed carbon electrode (SPCE). Then, a specific sequence of MTB DNA probe was immobilized onto a modified SPCE surface by using the 1-ethyl-3-(3-dimethylaminopropyl) carbodiimide/N-hydroxysuccinimide (EDC/NHS) coupling mechanism. For better signal amplification and electrochemical response, ruthenium bipyridyl $\mathrm{Ru}(\mathrm{bpy})_{3}{ }^{2+}$ was assigned as labels of hybridization followed by the characteristic test using differential pulse voltammetry (DPV). The results of this biosensor enable the detection of target DNA until a concentration as low as $7.96 \times 10^{-13} \mathrm{M}$ with a wide detection range from $1.0 \times 10^{-6}$ to $1.0 \times 10^{-12} \mathrm{M}$. In addition, the developed biosensor has shown a differentiation between positive and negative MTB samples in real sampel analysis.
\end{abstract}

Keywords: Mycobacterium tuberculosis; iron oxide; nanocellulose crystalline; cetyl trimethylammonium bromide; DNA biosensor 


\section{Introduction}

Mycobacterium tuberculosis (MTB) is an infectious bacterium responsible for tuberculosis (TB) pulmonary disease [1]. In 2018, around 10.0 million people were estimated to have positive symptoms related to TB (WHO, 2019). According to the report, TB affects people of both sexes of all ages. The largest group involves men rather than women (aged $\geq 15$ years), who accounted for $57 \%$ of all the cases. Among all TB cases, $8.6 \%$ were people living with HIV [2,3]. Various efforts have been carried out to improve TB diagnosis to reduce the number of deaths as set by the World Health Organization ( $80 \%$ reduction in TB incidence rate per year). These only can be achieved if the high-risk people are diagnosed correctly. Hence, the most effective treatment regimen should be started as early as possible. Over the past year, a complete medical evaluation for TB was based on laboratory diagnosis, majorly depending on the tuberculin skin test [4], chest radiography [5], acid fast bacilli (AFB) staining [6] and microbial culture [7]. These methods are accessible in developing countries; however, toxic reagents and more prolonged time of analysis are needed along with highly trained personnel for successful tests [8]. Furthermore, the implementation of nucleic acid amplification assays such as polymerase chain reaction (PCR) is limited by high cost and poor performance under extreme field conditions [9]. Therefore, there is a need to develop another fast screening method for in situ and real-time analysis.

Due to its considerable benefits, electrochemical means have become some of the most cost-effective analytical methods, particularly in sensing applications [10,11]. These advantages include rapid response, high sensitivity, low cost, and ease of use [12]. In recent years, electrochemical detection based on DNA hybridization exhibited excellent tools for DNA bioassay. Principally, this approach mainly relies on the response of current or resistance generated by the oxidation of guanine base and DNA intercalators [13]. Based on voltammetric methods, a metal complex has always been used as DNA intercalator for signal measurement between the electrode surface and DNA probes such as in the measurement of differential pulse voltammetry (DPV) and Squarewave voltammetry (SWV) [13,14]. Meanwhile, the use of a metal complex, especially tris(bipyridine) ruthenium (II), can be advantageous for the DNA electrochemical method to amplify the signal to obtain high sensitivity detection $[15,16]$. In order to increase the sensitivity of electrochemical biosensors, further modification is necessary to alter the surface of the electrode, particularly the conductivity of the electrode $[17,18]$. This can be achieved by tailoring the electrode surface with nanomaterials of high surface area and high catalytic activity with additional unique biocompatibility behaviour $[19,20]$. In this context, $\mathrm{Fe}_{3} \mathrm{O}_{4}$ offers tremendous potential advantages in the clinical and medical sensor, as reported in several studies [21,22]. Since $\mathrm{Fe}_{3} \mathrm{O}_{4}$ is highly hydrophobic, surface modification can be made through covalent bonding or physical adsorption using various biocompatible polymers [23]. Moreover, the high compatibility of $\mathrm{Fe}_{3} \mathrm{O}_{4}$ with other polymers offers a significant potential extent to improve the electrochemical performances of the respected biosensors. Nanocellulose crystalline (NCC) derived from biopolymer cellulose is a class of functional nanomaterial which exhibits promising potential for sensing application improvement. The NCC offers a plethora of outstanding properties, such as low toxicity, eco-friendly, high surface area, and good biocompatibility that can be functionalized easily by using different functional groups [24,25]. Previously, the NCC has been composited with polypyrrole [26], graphene oxide [27], gold nanoparticle [28], and has successfully become a scaffolding material for immobilization enzymes, DNA and other biomolecules to demonstrate the excellent synergistic effect that boosted electrochemical performance.

In this present study, we reported the development of electrochemical DNA biosensor based on $\mathrm{Fe}_{3} \mathrm{O}_{4}$ functionalized by 3-mercaptopropionic acid (MPA) through carboxyl (- $\mathrm{COOH}$ ) functional group (MPA- $\mathrm{Fe}_{3} \mathrm{O}_{4}$ ) and followed by composited with nanocellulose crystalline/cetyl trimethyl ammonium bromide (NCC/CTAB) and, finally became $\mathrm{MPA}-\mathrm{Fe}_{3} \mathrm{O}_{4} / \mathrm{NCC} / \mathrm{CTAB}$ on screen printed carbon electrode (SPCE). To achieve this goal, negatively charged MPA- $\mathrm{Fe}_{3} \mathrm{O}_{4}$ and positively charged NCC/CTAB were incorporated through ionic interaction as a matrix for conductivity enhancement, promoting an electron transfer and subsequently act as an immobilization platform for DNA. Although the detection mechanisms are already known, however, the use of nanoparticles polymer composites 
based on MPA-Fe $\mathrm{O}_{4} / \mathrm{NCC} / \mathrm{CTAB}$ with the use of $\mathrm{Ru}(\mathrm{bpy})_{3}{ }^{2+}$ as an electrochemical indicator has not yet been reported in any MTB assay. Therefore, the present study can also be considered as improving knowledge in the development of electrochemical DNA sensor. Furthermore, their interaction with the Ruthenium complex was able to differentiate between complementary, non-complementary and mismatch DNA for better sensitivity and selectivity of MTB detection.

\section{Results}

\subsection{The Field Emission Scanning Electron Microscopy (FESEM) Analysis}

FESEM results revealed that the morphology of the $\mathrm{Fe}_{3} \mathrm{O}_{4}$ in Figure $1 \mathrm{~A}$ shows an agglomerated and a spherical shape. Interestingly, functionalization with MPA has changed its structure to the bundling structure of nanowire compared to uncapped $\mathrm{Fe}_{3} \mathrm{O}_{4}$ (Figure 1B). Subsequently, in Figure 1C, FESEM image shows NCC morphology in the presence of CTAB displayed a nanocrystal aggregated in the form of bundles with a width of approximately $50 \mathrm{~nm}$ and a length of $200 \mathrm{~nm}$.
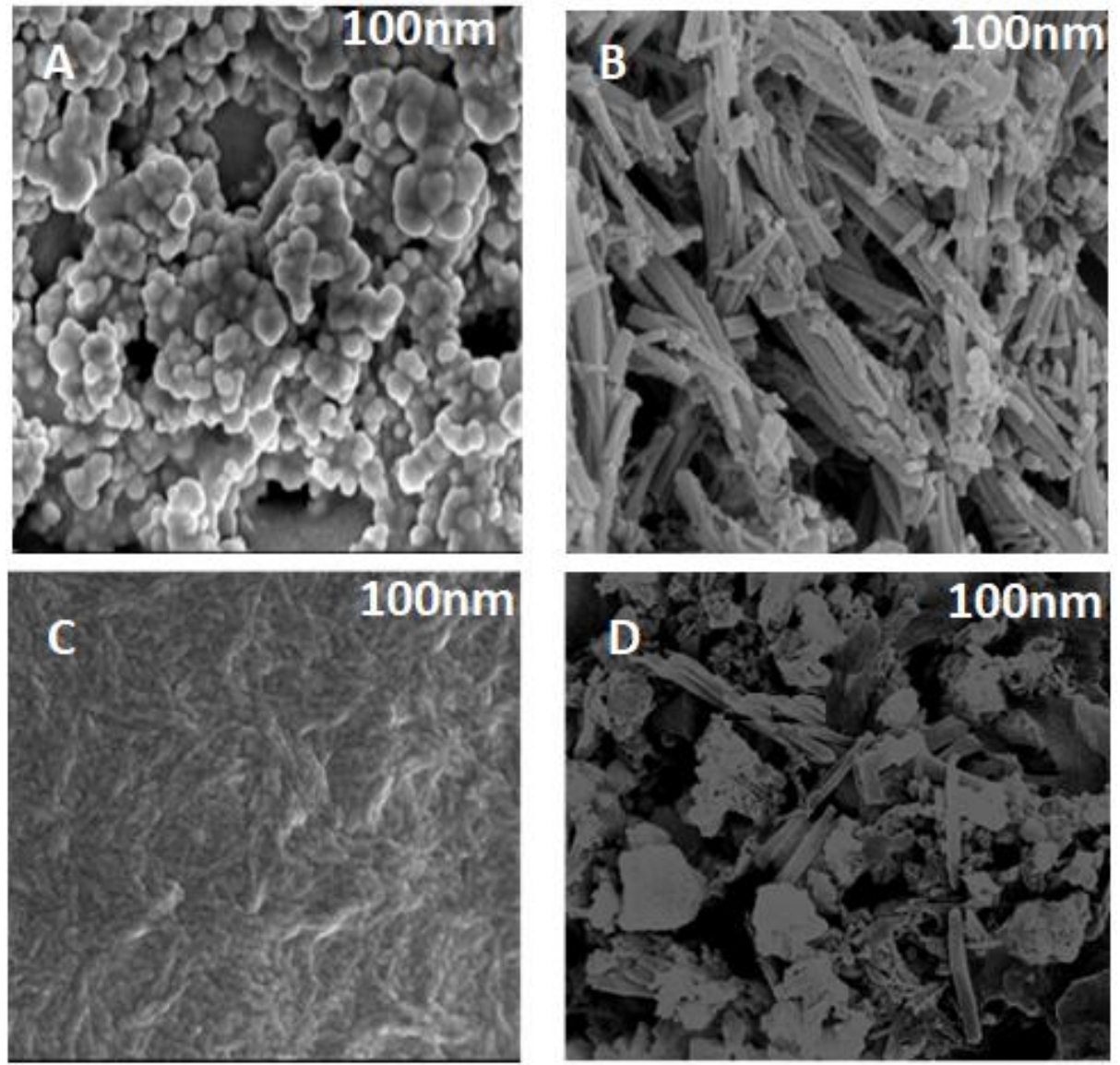

Figure 1. Field emission scanning electron microscopy (FESEM) images of the: (A) $\mathrm{Fe}_{3} \mathrm{O}_{4}$; (B) mercaptopropionic acid (MPA- $\left.\mathrm{Fe}_{3} \mathrm{O}_{4}\right)$; (C) nanocellulose crystalline functionalized cetyl trimethyl ammonium bromide (NCC/CTAB); (D) $\mathrm{MPA}-\mathrm{Fe}_{3} \mathrm{O}_{4} / \mathrm{NCC} / \mathrm{CTAB}$.

\subsection{Electrochemical Characterization}

To evaluate the interface properties of modified electrode, cyclic voltammetry (CV) was used in an electrochemical system to study acceleration electron transfer between the electrochemical probe and the electrode. In this study, $\mathrm{CV}$ experiments were carried out in $5 \mathrm{mM}$ of $\left(\mathrm{Fe}(\mathrm{CN})_{6}{ }^{3} / \mathrm{Fe}(\mathrm{CN})_{6}{ }^{4}\right)$ in $0.1 \mathrm{M}$ $\mathrm{KCl}$ consist of five different modified electrodes of (a) bare SPCE, (b) SPCE/Fe ${ }_{3} \mathrm{O}_{4}$, (c) SPCE/MPA-Fe $\mathrm{F}_{3} \mathrm{O}_{4}$, (d) SPCE/NCC/CTAB, and, (e) SPCE/MPA-Fe $\mathrm{O}_{4} / \mathrm{NCC} / \mathrm{CTAB}$ with scan rate $100 \mathrm{mV} / \mathrm{s}$ (Figure 2). The bare electrode of SPCE (curve a) exhibited a well-defined oxidation and reduction peaks in 
which the semi-reversible curve of $\mathrm{Fe}(\mathrm{CN})_{6}{ }^{3} / \mathrm{Fe}(\mathrm{CN})_{6}{ }^{4}$ peak was observed. Modification SPCE with $\mathrm{Fe}_{3} \mathrm{O}_{4}$ (curve b) showed an increase in the anodic peak current from 70.68 to $99.60 \mu \mathrm{A}$. Interestingly, functionalization of $\mathrm{Fe}_{3} \mathrm{O}_{4}$ with MPA on the SPCE (curve c) showed raises of current, $22.40 \mu \mathrm{A}$. On the other hand, after the modification with cationic surfactant of CTAB, as a nonconductive material, NCC displayed increasing peak current (curve d). Subsequently, after deposition of MPA-Fe $\mathrm{O}_{4} / \mathrm{NCC} / \mathrm{CTAB}$ on SPCE, a large increase in peak current $(177.18 \mu \mathrm{A})$ was observed. For comparison, bare SPCE has been studied using the same basic protocol. In this case, the CVs in $5.0 \mathrm{mM}\left[\mathrm{Fe}(\mathrm{CN})_{6}\right]^{4-/ 3-}$ solution containing $0.1 \mathrm{M} \mathrm{KCl}$ at different scan rates were used. The electroactive surface area of SPCE/MPA-Fe $\mathrm{O}_{4} / \mathrm{NCC} / \mathrm{CTAB}$ modified electrode was calculated based on the Randles-Sevcik equation ip $=2.69 \times 10^{5} \mathrm{n}^{3} / 2 \mathrm{AD}^{1 / 2} \mathrm{Cv}^{1 / 2}$, where ip = maximum current (ampere), $\mathrm{n}=$ number of electron transfer (in this work $\mathrm{n}=1), \mathrm{D}=$ diffusion coefficient $\left(\mathrm{cm}^{2} / \mathrm{s}\right)$ of $\left[\mathrm{Fe}(\mathrm{CN})_{6}\right]^{3-/ 4-}$ solution $\left(7.6 \times 10^{-6} \mathrm{~cm}^{2} / \mathrm{s}\right)$, $\mathrm{A}=$ electrode area $\left(\mathrm{cm}^{2}\right), \mathrm{C}=$ concentration $\left(\right.$ mole $\left.\cdot \mathrm{cm}^{-3}\right)$ and $\mathrm{v}=$ scan rate $(\mathrm{mV} / \mathrm{s})$ [29]. As a result, the calculation electroactive surface area of the $\mathrm{SPCE} / \mathrm{Fe}_{3} \mathrm{O}_{4} / \mathrm{NCC} / \mathrm{CTAB}$ modified electrode to be $0.167 \mathrm{~cm}^{2}$ as compared to the bare SPCE of $0.076 \mathrm{~cm}^{2}$. Moreover, the additional information from the plotted graph of anodic and cathodic peak currents against the square root of the scan rate displayed the linearity of the plots $\left(\mathrm{R}^{2}=0.998\right)$.
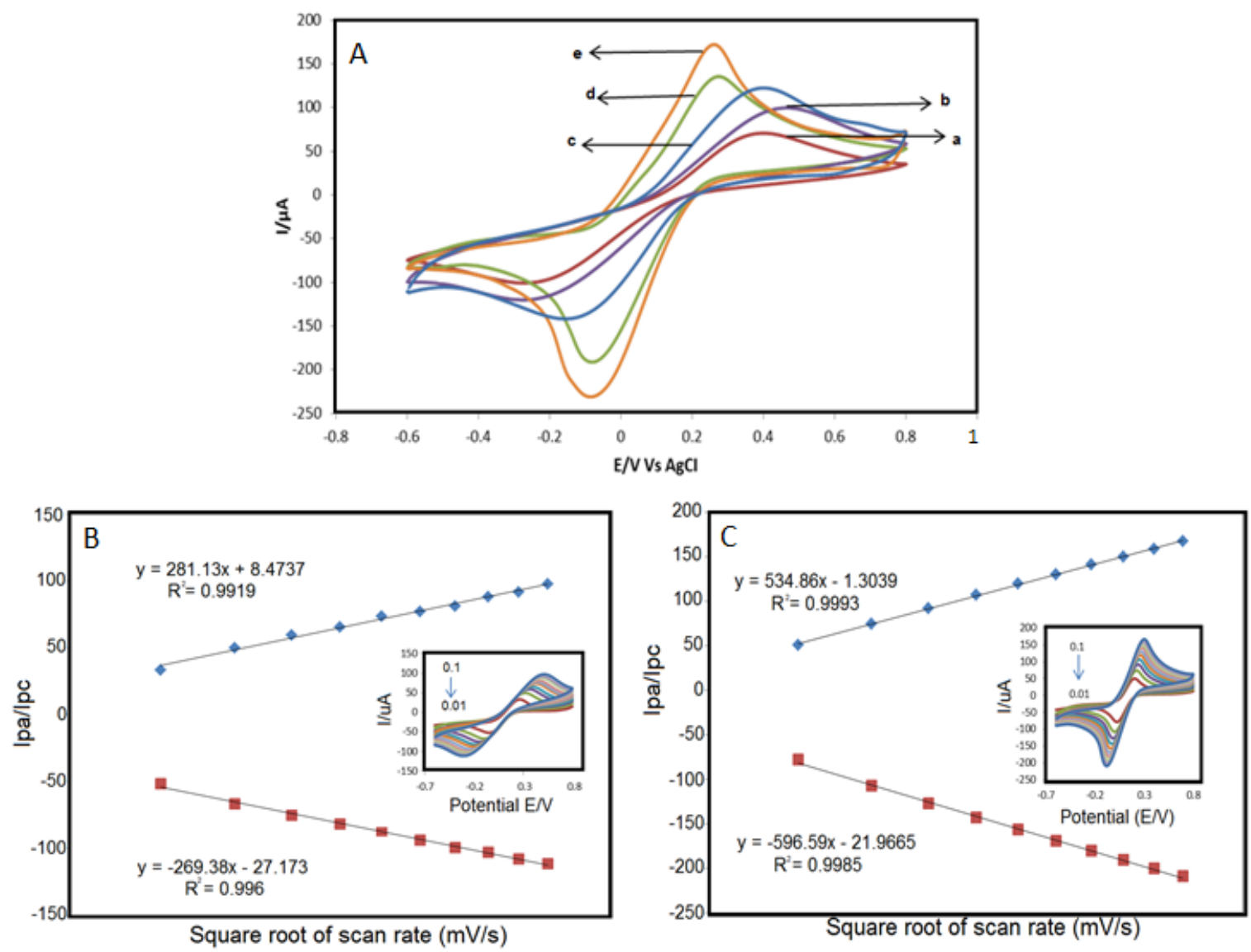

Figure 2. Cyclic voltammograms behavior: (A) (a) bare SPCE, (b) SPCE/ $/ \mathrm{Fe}_{3} \mathrm{O}_{4}$, (c) SPCE/MPA-Fe $\mathrm{O}_{4}$, (d) SPCE/NCC/CTAB and (e) SPCE/MPA-Fe ${ }_{3} \mathrm{O}_{4} / \mathrm{NCC} / \mathrm{CTAB}$ in $5.0 \mathrm{mM} \mathrm{K}_{3} \mathrm{Fe}(\mathrm{CN})_{6} / 0.1 \mathrm{M}$ KCI with scan rate, $100 \mathrm{mV} / \mathrm{s}$; (B) Plot of anodic and cathodic peak current (Ip) vs. square root of scan rate (V 1/2) of bare SPCE, and; (C) SPCE/MPA- $\mathrm{Fe}_{3} \mathrm{O}_{4} / \mathrm{NCC} / \mathrm{CTAB}$. 


\subsection{Electrochemical Performance of Fabricating Electrochemical DNA Biosensor}

Figure 3 shows current measurements in the presence of $\mathrm{Ru}(\mathrm{bpy})_{3}{ }^{2+}$, which consist of SPCE/MPA- $\mathrm{Fe}_{3} \mathrm{O}_{4} / \mathrm{NCC} / \mathrm{CTAB} / \mathrm{EDC} / \mathrm{NHS}$ (curve a), SPCE/MPA- $\mathrm{Fe}_{3} \mathrm{O}_{4} / \mathrm{NCC} / \mathrm{CTAB} / \mathrm{EDC} / \mathrm{NHS} / \mathrm{DNA}$ (curve b), $\mathrm{SPCE} / \mathrm{MPA}-\mathrm{Fe}_{3} \mathrm{O}_{4} / \mathrm{NCC} / \mathrm{CTAB} / \mathrm{EDC} / \mathrm{NHS} / \mathrm{DNA}-\mathrm{DNA}$ (curve c), respectively. In the absence of DNA, $\mathrm{Ru}(\mathrm{bpy})_{3}{ }^{2+}$ displayed the oxidation signal at $1.1 \mathrm{~V}$ and reduction signal at $0.8 \mathrm{~V}$ (curve a).

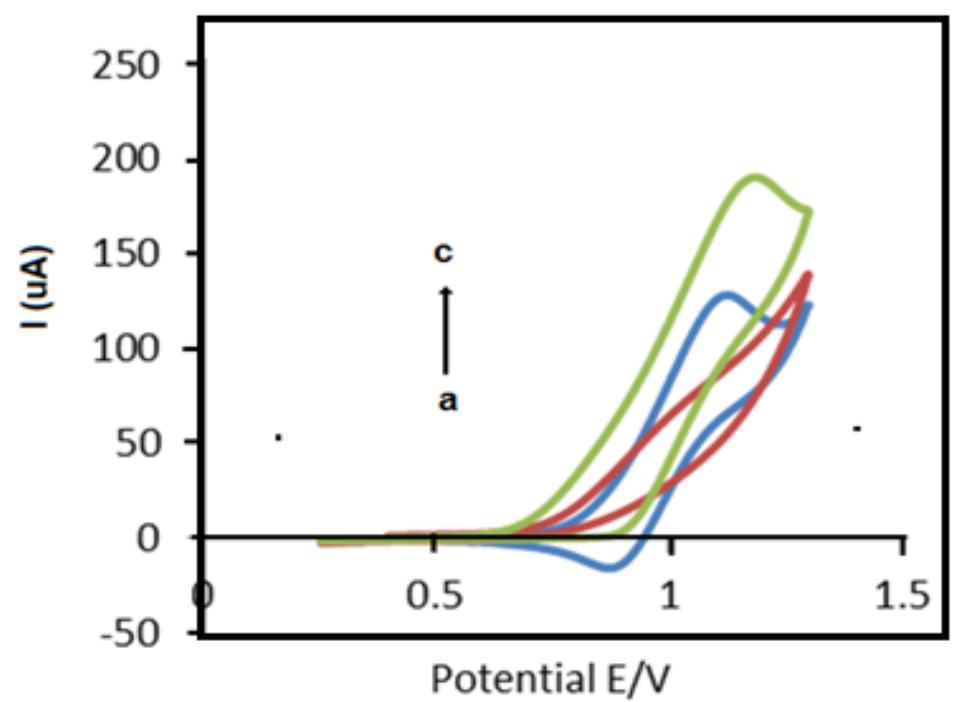

Figure 3. $\left[\mathrm{Ru}(\mathrm{bpy})_{3}\right]^{2+}$ current peak of the DNA biosensor by $\mathrm{CV}$ : (a) SPCE/MPA-Fe $\mathrm{O}_{4} / \mathrm{NCC} /$ EDC/NHS, (b) SPCE/MPA-Fe $\mathrm{O}_{4 /} \mathrm{NCC} / \mathrm{CTAB} / \mathrm{EDC} / \mathrm{NHS} / \mathrm{DNA}$, (c) SPCE/MPA-Fe $\mathrm{O}_{4} / \mathrm{NCC} / \mathrm{CTAB} /$ EDC/NHS/DNA-DNA target.

\subsection{Selectivity and Sensitivity of the Developed Electrochemical DNA Sensor}

Subsequently, the selectivity property of developed biosensor (curve a) was further investigated with single stranded DNA (ssDNA) (curve b), mutation DNA (curve c), non-complementary DNA (curve d) and complementary DNA (curve e) using DPV analysis as shown in Figure 4. It is pertinent to note that the peak current produced esulted from the $\mathrm{Ru}(\mathrm{bpy}){ }_{3}{ }^{2+}$ oxidation peak. As can be seen, the lowest peak current was observed on the DPV signal in the absence of DNA target on the modified electrode (curve a). Furthermore, various concentrations of ssDNA $\left(1.0 \times 10^{-6} \mathrm{M}\right.$ to $\left.1.0 \times 10^{-12} \mathrm{M}\right)$ were initially hybridized on the modified electrode. Subsequently, the current changes in DPV were recorded in $\mathrm{Ru}(\mathrm{bpy})_{3}{ }^{2+}$. Comparison between previous electrochemical studies using various nanomaterials and biomolecules, based on the screen-printed electrode for tuberculosis detection, is summarized in Table 1. 

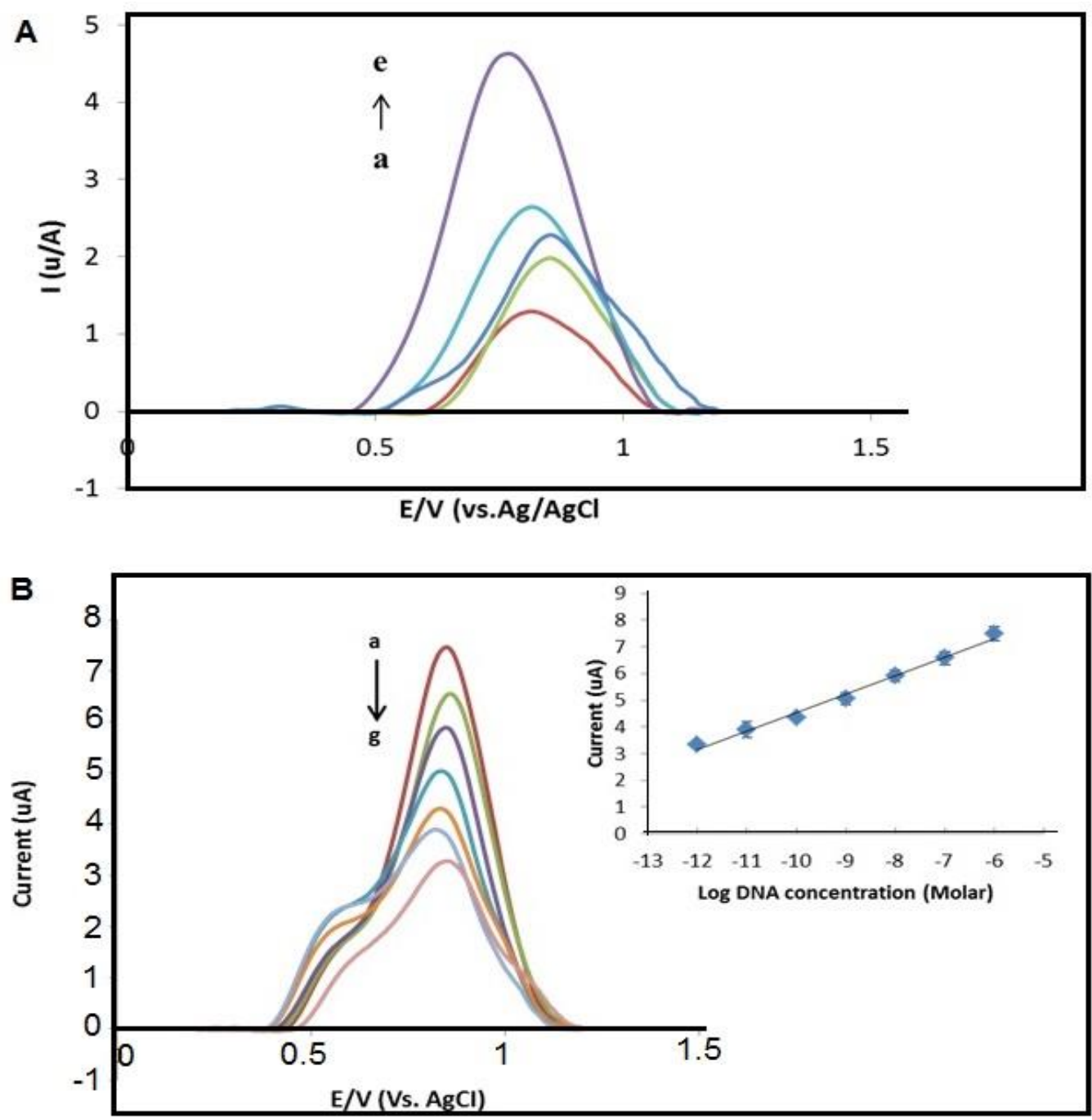

Figure 4. Differential pulse voltammetry (DPV) curve for oxidation of $\mathrm{Ru}(\mathrm{bpy})_{3}{ }^{2+}$ : (A) (a) SPCE/MPA-Fe $\mathrm{O}_{4} / \mathrm{NCC} / \mathrm{CTAB} / \mathrm{EDC} / \mathrm{NHS}$, (b) SPCE/MPA-Fe $\mathrm{O}_{4} / \mathrm{NCC} / \mathrm{CTAB} / \mathrm{EDC} / \mathrm{NHS} / \mathrm{DNA}$ probe, (c) $\mathrm{SPCE} / \mathrm{Fe}_{3} \mathrm{O}_{4} / \mathrm{NCC} / \mathrm{CTAB} / \mathrm{EDC} / \mathrm{NHS} /$ mutation-DNA, (d) SPCE/MPA-Fe $\mathrm{O}_{4} / \mathrm{NCC} / \mathrm{CTAB} /$ EDC/NHS/non-complementary-DNA, (e) SPCE/MPA-Fe $\mathrm{O}_{4}$ /NCC/CTAB/ EDC/NHS/DNA-DNA target, in TE buffer ( $\mathrm{pH} 8$ ) containing $25 \mu \mathrm{M} \mathrm{Ru}(\mathrm{bpy})_{3}{ }^{2+}$; (B) DPV curve at different concentration of complementary target DNA. Inset is a linear relationship between the DPV peak current (Ip) and the different concentrations of complementary DNA (from a to $g$ were $1.0 \times 10^{-6} \mathrm{M}$ to $1.0 \times 10^{-12} \mathrm{M}$ ) in TE buffer $\mathrm{pH} 7$.

Table 1. Comparison between the present work and other reported techniques for the detection of tuberculosis (TB) developed on screen-printed electrode.

\begin{tabular}{cccccc}
\hline Nanomaterial $^{\mathbf{1}}$ & Bio- Molecule & Inter- Calator & Limit of Detection & Real Sample & Reference \\
\hline Gr/ppy/SPCE & DNA & $\mathrm{MB}$ & $7.8 \times 10^{-7} \mathrm{M}$ & No & {$[30]$} \\
RGO/TNCC/SPCE & PNA & $\mathrm{MB}$ & $1 \times 10^{-13} \mathrm{M}$ & Yes & {$[25]$} \\
Gr/ppy/SPG & Antibody & - & $5 \mathrm{ng} / \mathrm{mL}$ & Yes & {$[31]$} \\
CdSe/ZnS & Antibody & $\mathrm{H}_{2} \mathrm{O}_{2}$ & $1.5 \times 10^{-10} \mathrm{~g} / \mathrm{mL}$ & No & {$[32]$} \\
QD/SiNP/SPCE & & $\mathrm{Ru}(\mathrm{bpy})_{3}{ }^{2+}$ & $7.96 \times 10^{-13} \mathrm{M}$ & Yes & This work \\
$\begin{array}{c}\mathrm{MPA}-\mathrm{Fe} \mathrm{O}_{3} / \mathrm{NCC} / \\
\mathrm{CTAB} / \mathrm{SPCE}\end{array}$ & $\mathrm{DNA}$ & $\mathrm{R}$ & & \\
\hline
\end{tabular}

${ }^{1} \mathrm{Gr} / \mathrm{ppy} / \mathrm{SPCE}$ (graphene/polypyrrole/screen printed carbon electrode); RGO/TNCC/SPCE (reduced graphene oxide/TEMPO-nanocellulose/screen printed carbon electrode); SPG (screen printed gold); CdSe/ZnS QD/SiNP/SPCE (cadmium selenide/zinc sulfide quantum dots/silica nanoparticles). 


\subsection{Detection of PCR Product of Mycobacterium Tuberculosis}

Several samples of Mycobacterium tuberculosis from PCR amplified product was tested as DNA target by using the developed electrochemical biosensor for applicability studies. In Figure 5A, the result from analyzed agarose gel electrophoresis separation showed a fragments band at $157 \mathrm{bp}$ was an indication of positive results related to MTB. Each line from agarose gel represent positive control (D1), negative control (D2), negative MTB sample (D3), MTB samples (D4, D5, D6 and D7), and Mycobacterium other than tuberculosis (MOTT), such as Staphylococcus aureus (D8), respectively. Subsequently, the same sample was evaluated by the fabricated DNA biosensor for real time setting, and the current produced was compared, as presented in Figure 5B,C. As a result, the DPV response showed an increase in the peak current using a positive control sample (Curve D1) and MTB positive samples (Curve D4, D5, D6, and D6) compared to ssDNA probe (Curve D0).

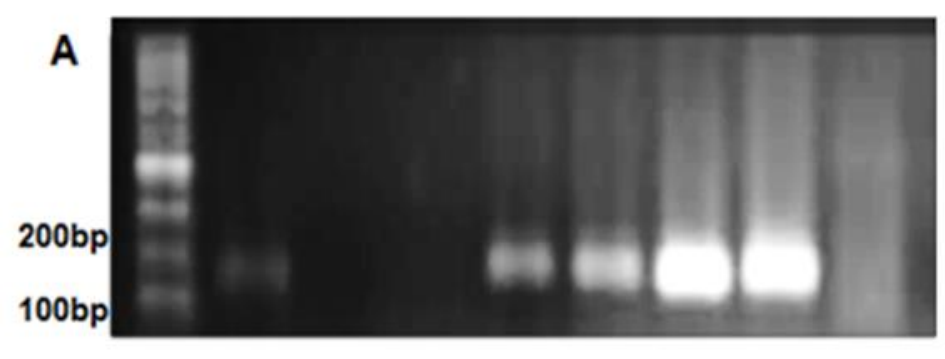

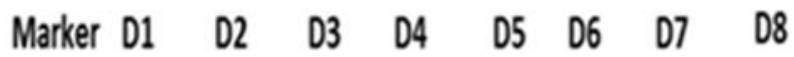
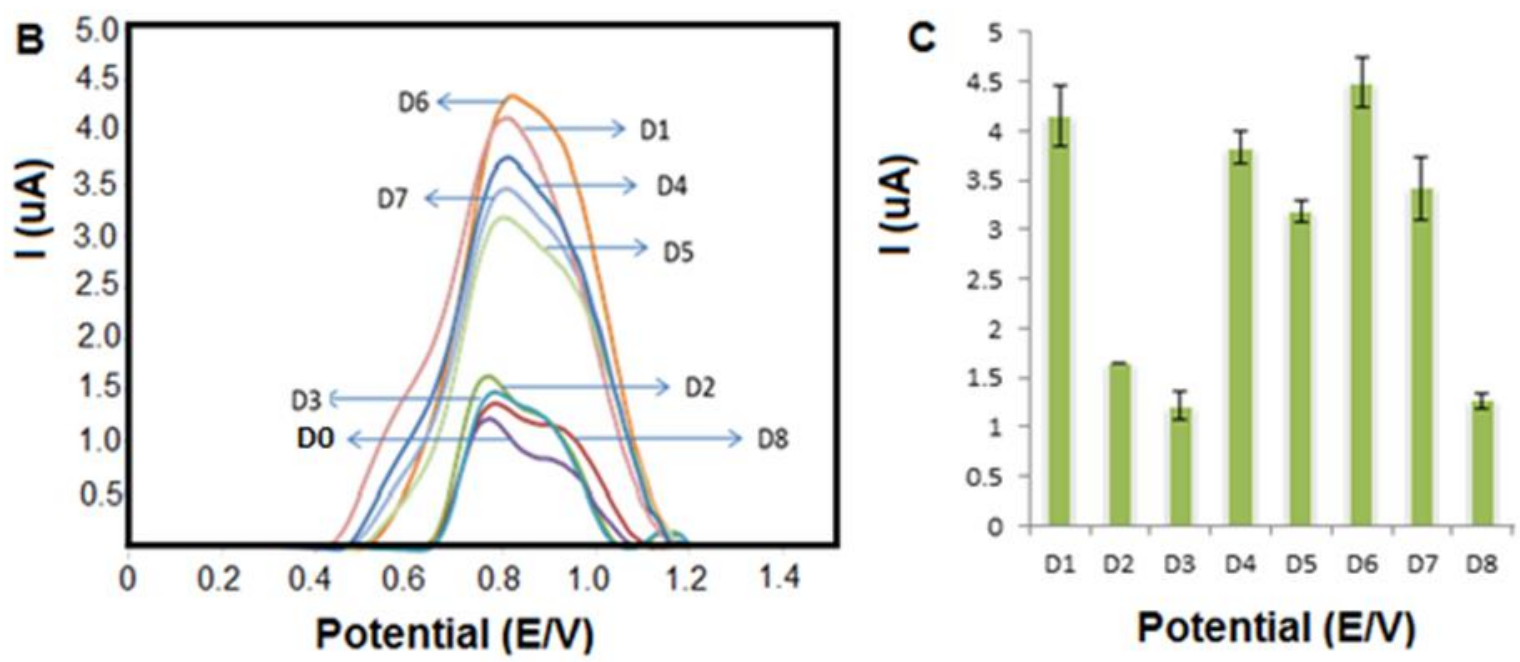

Figure 5. (A) Gel electrophoresis photographs of polymerase chain reaction (PCR) products obtained from D1 to D8; (B) DPV response for detection of D1 to D8 and; (C) DPV peak currents responding to the PCR products which was obtained from D1 to D8.

\section{Discussion}

\subsection{The Field Emission Scanning Electron Microscopy (FESEM) Analysis}

Figure 1A exhibited a result which is similar to the observation reported by previous study [33]. The bundling structure (Figure $1 \mathrm{~B}$ ) suggests the other way around forming $\mathrm{Fe}_{3} \mathrm{O}_{4}$ slender structures like nanowire array without the need for any precipitation and a subsequent microwave hydrothermal process, as reported in the previous study [34]. The agglomeration of the nanocrystals (Figure 1C) might be due to the evaporation of water during the sample preparation [35]. Subsequently, the morphology of the resulting composites of $\mathrm{MPA}-\mathrm{Fe}_{3} \mathrm{O}_{4} / \mathrm{NCC} / \mathrm{CTAB}$ showed the bulky nanoparticle agglomerated 
together (Figure 1D). This could be due to intermolecular forces that mediated the interaction between the molecules of the nanoparticles.

\subsection{Electrochemical Characterization}

The modified SPCE with $\mathrm{Fe}_{3} \mathrm{O}_{4}$ (curve b) was able to facilitate the electron transfer kinetics in order to offer much higher conductivity [36]. Furthermore, the functionalization of $\mathrm{Fe}_{3} \mathrm{O}_{4}$ with MPA (curve c) was able to assist electron acceleration to the electrode surface. On the other hand, the SPCE modification with CTAB and NCC exhibited the synergistic effect between MPA-Fe $\mathrm{O}_{4}$ and $\mathrm{NCC} / \mathrm{CTAB}$ to facilitate the electron transfer kinetics of $\mathrm{Fe}(\mathrm{CN})_{6}{ }^{3} / \mathrm{Fe}(\mathrm{CN})_{6}{ }^{4}$ (curve e). In addition, a further experiment was performed to calculate the real electroactive area, an important parameter to be considered in the development of electrochemical DNA biosensor. The results from CV demonstrate that CTAB was able to provide conductive properties to NCC in order to accelerate the electron transfer on the electrode surface. As previously reported, the introduction of the CTAB surfactant has increased the dispersion of cellulose nanocrystals (CNCs) and the dispersive effect of nanoparticles increases the conductive probability $[27,37]$. The results also show that the electroactive surface area of SPCE/MPA- $\mathrm{Fe}_{3} \mathrm{O}_{4} / \mathrm{NCC} / \mathrm{CTAB}$ was increased by approximately $54.5 \%$ compared to the bare SPCE. This increment shows the ability of the developed electrochemical for providing a wide area platform [32] for DNA immobilization; thus, it can influence the sensitivity of detection [18,38]. Furthermore, the linearity of the plots has suggested that the electron transfer occurred was due to the diffusion-controlled electron transfer process [27,39].

\subsection{Electrochemical Performance of Fabricating Electrochemical DNA Biosensor}

The use of $\mathrm{Ru}(\mathrm{bpy})_{3}{ }^{2+}$ as the electrochemical indicator was expected to be able to distinguish between single stranded DNA (ssDNA) and double stranded DNA (dsDNA) to achive a highly sensitive response from the developed biosensor. As previously reported, there are at least three DNA-binding modes with metal complexes available, consisting of electrostatic attraction, intercalation, and groove binding $[40,41]$. In this study, the interaction between positive charges of $\mathrm{Ru}(\mathrm{bpy})_{3}{ }^{2+}$ and negative charges of DNA could occur with combinations of all of these modes. Furthermore, the increase in the peak current after the DNA hybridization suggested that $\mathrm{Ru}(\mathrm{bpy})_{3}{ }^{2+}$ binds to the groove of the DNA duplex in which the interaction occurred between the $\mathrm{Ru}(\mathrm{bpy})_{3}{ }^{2+}$ and the phosphate backbone, indicating the intercalation of long-range guanine oxidation in DNA duplexes [42].

\subsection{Selectivity and Sensitivity of the Developed Electrochemical DNA Sensor}

The drastically increased DPV peak current was observed after DNA immobilization on the modified electrode indicating successful Ru(bpy $)_{3}{ }^{2+}$ intercalation into the DNA (curve b). Furthermore, the highest peak current was shown after hybridization with the complementary target DNA (curve e), indicating that a large amount of $\mathrm{Ru}(\mathrm{bpy})_{3}{ }^{2+}$ interacted with dsDNA through the binding modes mechanism, as mentioned in Section 3.3. Moreover, it is apparent from this study that the binding between DNA and mutation DNA (curve c) resulting in an insignificant increase in current due to non-specific binding. This result shows the ability of the developed electrochemical biosensor to discern the DPV signal between complementary DNA, mutation DNA, and non-complementary DNA in the presence of $\mathrm{Ru}(\mathrm{bpy})_{3}{ }^{2+}$. The results also show that the oxidation peak increased linearly with the increased concentration of complementary target DNA correspond with the linear calibration curve obtained in Figure 4B [Y $=0.6936 \log (X)+11.47]$ where $Y$ is the peak current and $\log (X)$ is the logarithm of the target DNA concentration with a correlation coefficient of $R^{2}=0.9896$. Meanwhile, the limit of detection (LOD) was calculated based on $3 \sigma / S$ [18] where $\sigma$ is the relative standard deviation (RSD) of blank $(n=3)$ and $S$ represents slope of calibration curve with the LOD obtained was $7.96 \times 10^{-13} \mathrm{M}$. The reproducibility of the fabricated DNA sensor was evaluated by using an eight replicate system with the RSD value calculated to be at $3.87 \%(n=8)$. The results indicate that the method is consistent within the error limit and meaningful for the designed biosensor. Furthermore, 
the stability study of the fabricated DNA sensor displayed a good result after it was stored at $4{ }^{\circ} \mathrm{C}$ for 7 days with minimum loss of activity. The comparison results from Table 1 clearly indicate that the developed DNA biosensor displayed a good analytical performance if compared to the previous reported electrochemical biosensor in terms of the limit of detection.

\subsection{Detection of PCR Product of Mycobacterium Tuberculosis}

The developed electrochemical biosensor was exposed to PCR product from real sample MTB. Compared to traditional PCR, the developed electrochemical biosensor does not require a step of visualization of amplified products by gel electrophoresis, which may be time-consuming and costly. Following the preparation step for electrode hybridization, as mentioned in Section 4.9, it can be seen that the higher peak current produced resulted from complementary binding between the ssDNA probe and MTB-positive sample on the modified electrode. Meanwhile, the DPV response for D2, D3, and D8 samples resulted in a decreased current response compared to D1, D4, D5, D6 and D7 sample indicated to the lack of hybridization occurred between DNA probe and PCR product. In the absence of the hybridization case, this is possibly due to the non-specific interaction, which is in agreement with the DPV analysis using synthetic DNA (Figure 4A). The results from this study show that a significant DPV response was obtained to distinguish a signal between positive and negative MTB and, therefore, the fabricated electrochemical DNA sensor demonstrated good potential for selectivity and effectively detection toward the MTB from the PCR product.

\section{Materials and Methods}

\subsection{Reagents}

Iron oxide $\left(\mathrm{Fe}_{3} \mathrm{O}_{4}\right)$ was obtained from Materials Synthesis and Characterization Laboratory, Institute of Advanced Technology, Universiti Putra Malaysia (ITMA). Tris (2,2'-bypridyl) dichlororuthenium(II) hexahydrate $\left(\mathrm{Ru}(\mathrm{bpy})^{2+}\right)$, cetyltrimethylammonium bromide (CTAB), ethylenediaminetetraacetic acid (EDTA), Tris $\mathrm{HCI} \mathrm{NH}_{2} \mathrm{C}\left(\mathrm{CH}_{2} \mathrm{OH}\right)_{3} \cdots \mathrm{HCl}$, potassium ferricyanide $\left(\mathrm{K}_{3}\left[\mathrm{Fe}(\mathrm{CN})_{6}\right]\right)$, and N-hydroxysuccinimide (NHS) were obtained from Sigma-Aldrich (Steinheim, Germany). Cellulose nanocrystalline (NCC) was purchased from the Process Development Centre, University of Maine. N-ethyl-N-(3-(dimethylaminopropyl) carbodiimide (EDC) was bought from Fluka (Switzerland). 3-mercaptopropanoic acid (MPA) was purchased from R \& M chemicals. All other chemicals were of analytical reagent grade. Meanwhile, synthesized oligomers were purchased from 1st Based Laboratory Sdn. Bhd., Malaysia and based on sequences listed in Table 2 below:

Table 2. Oligonucleotide sequences used in this works.

\begin{tabular}{cc}
\hline Name of the DNA Strand & DNA Sequences \\
\hline Amine Probe DNA & $5^{\prime}-/ 5$ AmMC12/CTC GTC CAG CGC CGC TTC GG-3' \\
Target DNA & $5^{\prime}$-CCG AAG CGG CGC TGG ACG AG-3' \\
non-complementary DNA & $5^{\prime}$-TTT GGT ATT ATT GTT CAT GT-3' \\
Mutation DNA & $5^{\prime}$-CTC GTC CAG CGC CIC TTC GG-3' \\
Primer MTB Forward & $5^{\prime}-$ CGT GAG GGC ATC GAG GTG GC-3' \\
Primer MTB Reverse & $5^{\prime}$-GCG TAG GCG TCG GTG ACG AA-3' \\
\hline
\end{tabular}

\subsection{Real Sample Application}

The genomic DNA of the MTB was extracted from the sputums of patients who were diagnosed with TB (positive), which were provided by the Institute for Medical Research (IMR), Malaysia. In order to amplify the obtained products, polymerase chain reaction (PCR) was carried out using the mixture of primers, as stated in Table 1. After 30 cycles of PCR, the products obtained were identified by running $5 \mu \mathrm{L}$ of a PCR mixture in $1.0 \%$ agarose gel for $45 \mathrm{~min}$ and were examined under ultraviolet light. The agarose gel electrophoresis for the positive TB sample revealed products at fragment sizes of 
$157 \mathrm{bp}$, while no band appears to indicate a negative result. Meanwhile, denatured single-stranded DNA (ssDNA) was obtained by heating dsDNA in a water bath between 50 and $60^{\circ} \mathrm{C}$ for $10 \mathrm{~min}$, followed by rapid cooling in an ice bath.

\subsection{Preparations of Stock Solutions}

DNA oligomers $(100 \mu \mathrm{M})$ were prepared in Tris EDTA (TE) buffer solution containing $10 \mathrm{mM}$ Tris-HCI and $1 \mathrm{mM} \mathrm{EDTA} \mathrm{(} \mathrm{pH} 8.0)$, labeled as "stock solution" and kept frozen at $-20^{\circ} \mathrm{C}$. When required, probe DNA, target DNA, non-complimentary DNA and mutation DNA were defrosted, and diluted concentrations were prepared using TE buffer containing $20 \mathrm{mM} \mathrm{NaCI}$.

\subsection{Instrumentation}

Screen printed carbon electrodes (SPCEs) were purchased from Dropsens (Asturias, Spain), and consisted of the working electrode (carbon), reference electrode (Ag), and auxiliary electrode (carbon). Voltammetric measurements were obtained using the Autolab (Ecochemie, Utrecht, The Netherlands) potentiostat incorporated with a general-purpose electrochemical system (NOVA 1.11).

\subsection{Preparation of $\mathrm{MPA}-\mathrm{Fe}_{3} \mathrm{O}_{4}$}

The capping process was based on previous work with slight modification [28]. Firstly, $1 \mathrm{wt} \%$ of $\mathrm{Fe}_{3} \mathrm{O}_{4}$ was mixed with MPA using a mole ratio of 1:30 in deionized water and shaken for overnight. The particles were washed and dried at room temperature. MPA- $\mathrm{Fe}_{3} \mathrm{O}_{4}(5 \mathrm{mg})$ was dissolved with $1 \mathrm{~mL}$ deionized water and mixed.

\subsection{Preparation of NCC/CTAB}

Modification of NCC with CTAB was prepared as previously described with slight modifications [43]. Firstly, $1 \mathrm{~g}$ NCC ( $1 \mathrm{wt} \%$ suspension at $\mathrm{pH} 10$ adjusted using $1 \mathrm{M} \mathrm{NaOH})$ along with $1 \mathrm{wt} \%$ aqueous CTAB solution with 2:1 ratio between CTAB to sulfur was prepared. The suspension of NCC was added slowly to the CTAB solution, and the foamy mixture was maintained at $60^{\circ} \mathrm{C}$ for $3 \mathrm{~h}$ and left stirring overnight at room temperature. Afterwards, the samples were washed to remove the unbound $\mathrm{CTAB}$ by centrifugation at $10,000 \mathrm{rpm}$ for $10 \mathrm{~min}$.

\subsection{Preparation of $\mathrm{MPA}-\mathrm{Fe}_{3} \mathrm{O}_{4} / \mathrm{Ncc} / \mathrm{Ctab}$}

The solution of MPA-Fe $\mathrm{O}_{4}$ and NCC/CTAB was mixed well-using volume ratio of 1:1. Prior to the SPCE modification, $7 \mu \mathrm{L}$ MPA- $\mathrm{Fe}_{3} \mathrm{O}_{4} / \mathrm{NCC} / \mathrm{CTAB}$ was prepared using drop casting method on the SPCE and dried at room temperature overnight.

\subsection{Immobilization of DNA Probe onto Modified SPCE/MPA-Fe ${ }_{3} \mathrm{O}_{4} / \mathrm{Ncc} / \mathrm{Ctab}$}

The modified SPCE was immersed in $5 \mathrm{mM}$ EDC and $2 \mathrm{mM}$ NHS containing $50 \mathrm{mM}$ PBS (pH 5.2) for $10 \mathrm{~min}$ at room temperature. Subsequently, $2 \mu \mathrm{L}$ of probe DNA $(10 \mu \mathrm{M})$ was dropped onto the surface of modified SPCE and incubated at room temperature for $1 \mathrm{~h}$. The electrode was then washed with TE buffer for $30 \mathrm{~s}$. The washed electrode was denoted as SPCE/MPA- $-\mathrm{Fe}_{3} \mathrm{O}_{4} / \mathrm{NCC} /$ CTAB/EDC/NHS/DNA throughout.

\subsection{Hybridization of DNA}

Subsequent process was performed by hybridized $2 \mu \mathrm{L}$ of complementary ssDNA on $\mathrm{SPCE} / \mathrm{MPA}-\mathrm{Fe}_{3} \mathrm{O}_{4} / \mathrm{NCC} / \mathrm{CTAB} / \mathrm{EDC} / \mathrm{NHS} / \mathrm{DNA}$ probe as above with desired concentration and incubated for $25 \mathrm{~min}$ at room temperature. The successful hybridize complimentary DNA on the modified SPCE was washed with TE buffer ( $\mathrm{pH} 7)$ and purged with nitrogen gas $\left(\mathrm{N}_{2}\right)$. Subsequently, electrochemical signals of ruthenium bypridyl $\left(\mathrm{Ru}(\mathrm{bpy})_{3}{ }^{2+}\right)$ bound to signal DNA were measured by differential pulse voltammetry (DPV). Hybridization was monitored using different target DNA 
concentrations ranging from $1.0 \times 10^{-7}$ to $1.0 \times 10^{-13} \mathrm{M}$, followed by non-complimentary DNA, mutation DNA, and DNA from clinical samples (from IMR). The fabrication procedure of the DNA electrochemical biosensor can be viewed as illustrated in Scheme 1.

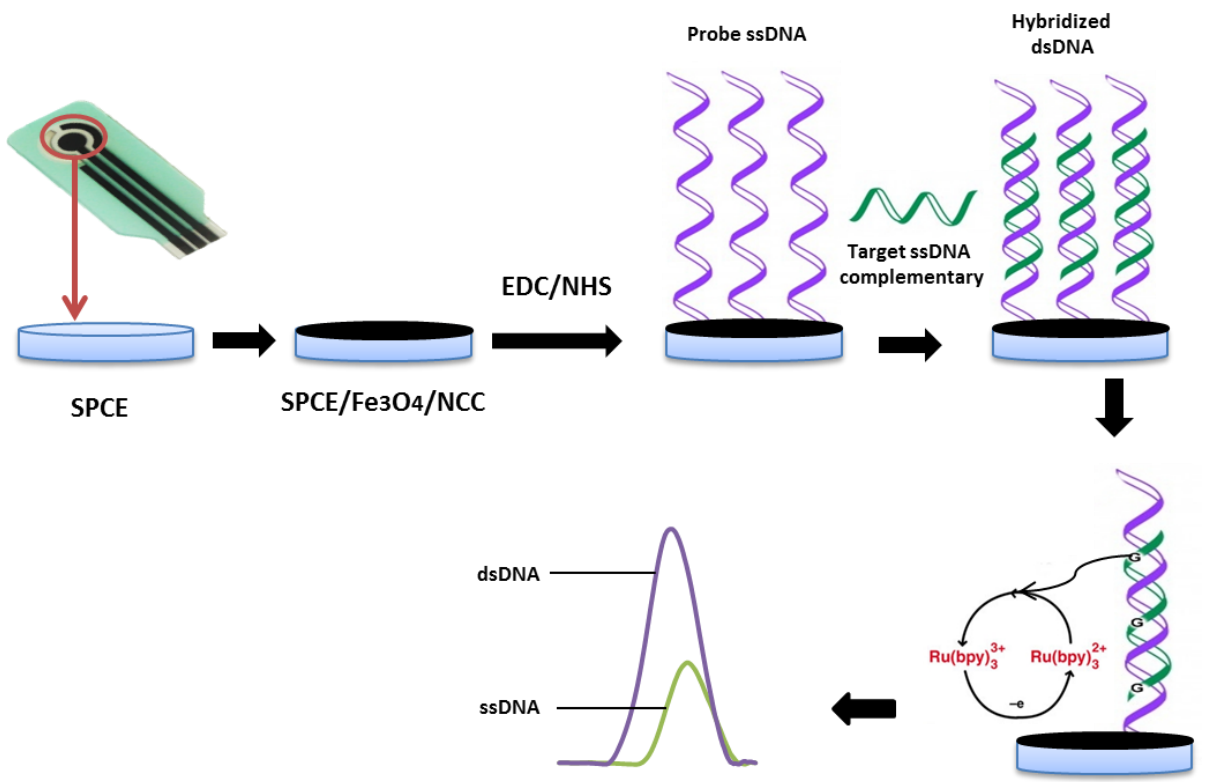

Scheme 1. Stepwise of the experimental procedure for the preparation of $\mathrm{MPA}^{-} \mathrm{Fe}_{3} \mathrm{O}_{4}$ composited nanocellulose.

\section{Conclusions}

The present study demonstrated a sensitive electrochemical DNA biosensor platform based on a new composite nanomaterial. The combination of $\mathrm{MPA}-\mathrm{Fe}_{3} \mathrm{O}_{4}$ and $\mathrm{NCC} / \mathrm{CTAB}$ was successfully prepared for the immobilization of the capture probe to be hybridized with the complementary target DNA of MTB. Detection of complementary target DNA ranging from $1.0 \times 10^{-12}$ to $1.0 \times 10^{-6} \mathrm{M}$ was obtained with a limit of detection of $7.96 \times 10^{-13} \mathrm{M}$. The DPV analysis showed that the fabricated DNA electrochemical biosensor exhibited high sensitivity and specificity with the synthetic DNA and also the clinical sample from the PCR product (MTB). The developed biosensor also demonstrated a differentiation to the interferences such as negative MTB, Mycobacterium other than tuberculosis, and the respiratory-related bacterial sample such as Staphylococcus aureus. These characteristics make the fabricated biosensor an attractive alternative for the in site application and can provide a promising platform for rapid diagnosis of tuberculosis.

Author Contributions: Conceptualization, M.H.M.Z. and C.E.N.C.-E.-C.; methodology, N.A.Y. and J.A.; validation, R.I., J.A. and H.W.; formal analysis, C.E.N.C.-E.-C.; resources, N.A.Y., R.I. and M.F.M.N.; data curation, S.S.O.; writing-original draft preparation, M.H.M.Z. and C.E.N.C.-E.-C.; writing-review and editing, H.W., and S.S.O.; funding acquisition, H.W., N.A.Y.; supervision, H.W. All authors have read and agreed to the published version of the manuscript.

Funding: The authors are grateful for the financial support provided by Ministry of Education of Malaysia through Universiti Putra Malaysia under Science fund (03-01-04-SF2045), Inisiatif Putra Berkumpulan (GP-IPB/2013/9412700), Inisiatif Pelajar Siswazah (GP-IPS/2017/9527100), Grant Putra (GP/2018/9646800) and Modal Insan grant under University Kebangsaan Malaysia (MI-01-2019).

Acknowledgments: We would like to thank the members of Institute of Medical Research (IMR) and postgraduate lab members of faculty sciences, University Putra Malaysia 2017/2018 (UPM).

Conflicts of Interest: The author declares that there is no conflict of interest. 


\section{References}

1. Ryndak, M.B.; Laal, S. Mycobacterium tuberculosis Primary Infection and Dissemination: A Critical Role for Alveolar Epithelial Cells. Front. Cell. Infect. Microbiol. 2019, 9, 299. [CrossRef] [PubMed]

2. World Health Organization (WHO). The WHO global TB database in Global Tuberculosis Report 2019. 2019. Available online: https://www.who.int/tb/publications/global_report/en/ (accessed on 17 October 2019).

3. Taxonera, C.; Ponferrada, A.; Riestra, S.; Bermejo, F.; Saro, C.; Martin-Arranz, M.D.; Cabriada, J.L.; Barreiro-de Acosta, M.; de Castro, M.L.; Lopez-Serrano, P.; et al. Serial Tuberculin Skin Tests Improve the Detection of Latent Tuberculosis Infection in Patients With Inflammatory Bowel Disease. J. Crohns. Colitis 2018, 12, 1270-1279. [CrossRef] [PubMed]

4. Nayak, S.; Acharjya, B. Mantoux test and its interpretation. Indian Dermatol. 2012, 3, 2-6. [CrossRef]

5. Jaeger, S.; Karargyris, A.; Candemir, S.; Siegelman, J.; Folio, L.; Antani, S.; Thoma, G. Automatic Screening for Tuberculosis in Chest Radiographs: A Survey. Quant. Imaging Med. Surg. 2013, 3, 89-99.

6. Pokam, B.T.; Asuquo, A.E. Acid-Fast Bacilli Other than Mycobacteria in Tuberculosis Patients Receiving Directly Observed Therapy Short Course in Cross River State, Nigeria. Tuberc. Res. Treat. 2012, 2012, 301056. [CrossRef] [PubMed]

7. Dunn, J.J.; Starke, J.R.; Revell, P.A. Laboratory Diagnosis of Mycobacterium tuberculosis Infection and Disease in Children. J. Clin. Microbiol. 2016, 54, 1434-1441. [CrossRef]

8. Parsons, L.M.; Somoskovi, A.; Gutierrez, C.; Lee, E.; Paramasivan, C.N.; Abimiku, A.; Spector, S.; Roscigno, G.; Nkengasong, J. Laboratory Diagnosis of Tuberculosis in Resource-Poor Countries: Challenges and Opportunities. Clin. Microbiol. Rev. 2011, 24, 314-350. [CrossRef]

9. Fakruddin, M.; Mannan, K.S.; Chowdhury, A.; Mazumdar, R.M.; Hossain, M.N.; Islam, S.; Chowdhury, M.A. Nucleic acid amplification: Alternative methods of polymerase chain reaction. J. Pharm. Bioallied Sci. 2013, 5, 245-252. [CrossRef]

10. Noviana, E.; McCord, C.P.; Clark, K.M.; Jang, I.; Henry, C.S. Electrochemical paper-based devices: Sensing approaches and progress toward practical applications. Lab. Chip. 2020, 20, 9-34. [CrossRef]

11. Kimmel, D.W.; LeBlanc, G.; Meschievitz, M.E.; Cliffel, D.E. Electrochemical Sensors and Biosensors. Anal. Chem. 2012, 84, 685-707. [CrossRef]

12. Maduraiveeran, G.; Sasidharan, M.; Ganesan, V. Electrochemical sensor and biosensor platforms based on advanced nanomaterials for biological and biomedical applications. Biosens. Bioelectron. 2018, 103, 113-129. [CrossRef] [PubMed]

13. Qi, H.; Li, X.; Chen, P.; Zhang, C. Electrochemical detection of DNA hybridization based on polypyrrole/ss-DNA/multi-wall carbon nanotubes paste electrode. Talanta 2007, 72, 1030-1035. [CrossRef] [PubMed]

14. Abu-Salah, K.M.; Zourob, M.M.; Mouffouk, F.; Alrokayan, S.A.; Alaamery, M.A.; Ansari, A.A. DNA-Based Nanobiosensors as an Emerging Platform for Detection of Disease. Sensors 2015, 15, 14539-14568. [CrossRef] [PubMed]

15. Zhang, S.; Ding, Y.; Wei, H. Ruthenium Polypyridine Complexes Combined with Oligonucleotides for Bioanalysis: A Review. Molecules 2014, 19, 11933-11987. [CrossRef]

16. Dutse, S.W.; Yusof, N.A.; Ahmad, H.; Zainal, M.Z.H.Z. An Electrochemical DNA Biosensor for Ganoderma boninense Pathogen of the Oil Palm Utilizing a New Ruthenium Complex, $\left[\mathrm{Ru}(\mathrm{dppz})^{2}(\mathrm{qtpy}) \mathrm{Cl}_{2}\right.$. Int. J. Electrochem. Sci. 2012, 7, 8105-8115.

17. Krishnan, S.K.; Singh, E.; Singh, P.; Meyyappan, M.; Nalwa, H.S. A review on graphene-based nanocomposites for electrochemical and fluorescent biosensors. RSC Adv. 2019, 9, 8778-8881. [CrossRef]

18. Mat Zaid, M.H.; Abdullah, J.; Yusof, N.A.; Wasoh, H.; Sulaiman, Y.; Md Noh, M.F.; Issa, R. PNA biosensor based on reduced graphene oxide/water soluble quantum dots for the detection of Mycobacterium tuberculosis. Sens. Actuators B-Chem. 2017, 241, 1024-1034. [CrossRef]

19. Khan, I.; Saeed, K.; Khan, I. Nanoparticles: Properties, applications and toxicities. Arab. J. Chem. 2019, 12, 908-931. [CrossRef]

20. Lin, P.H.; Li, B.R. Antifouling strategies in advanced electrochemical sensors and biosensors. Analyst 2020, 145, 1110-1120. [CrossRef] 
21. Arani, N.H.; Ghoreishi, S.M.; Khoobi, A. Increasing the electrochemical system performance using a magnetic nanostructured sensor for simultaneous determination of l-tyrosine and epinephrine. Anal. Methods. 2019, 11, 1192-1198. [CrossRef]

22. Zhang, W.; Li, X.; Zou, R.; Wu, H.; Shi, H.; Yu, S.; Liu, Y. Multifunctional glucose biosensors from $\mathrm{Fe}_{3} \mathrm{O}_{4}$ nanoparticles modified chitosan/graphene nanocomposites. Sci. Rep. 2015, 5, 11129. [CrossRef] [PubMed]

23. Xu, J.-K.; Zhang, F.-F.; Sun, J.-J.; Sheng, J.; Wang, F.; Sun, M. Bio and Nanomaterials Based on Fe ${ }_{3} \mathrm{O}_{4}$. Molecules 2014, 19, 21506-21528. [CrossRef] [PubMed]

24. Dumanli, A.G. Nanocellulose and its Composites for Biomedical Applications. Curr. Med. Chem. 2017, 24, 512-528. [CrossRef] [PubMed]

25. Trache, D.; Tarchoun, A.F.; Derradji, M.; Hamidon, T.S.; Masruchin, N.; Brosse, N.; Hussin, M.H. Nanocellulose: From Fundamentals to Advanced Applications. Front Chem. 2020, 8, 392. [CrossRef]

26. Esmaeili, C.; Abdi, M.M.; Mathew, A.P.; Jonoobi, M.; Oksman, K.; Rezay, M. Synergy Effect of Nanocrystalline Cellulose for the Biosensing Detection of Glucose. Sensors 2015, 15, 24681-24697. [CrossRef]

27. Zaid, M.H.M.; Abdullah, J.; Yusof, N.A.; Wasoh, H.; Sulaiman, Y.; Noh, M.F.M.; Issa, R. Reduced Graphene Oxide/TEMPO-Nanocellulose Nanohybrid-Based Electrochemical Biosensor for the Determination of Mycobacterium tuberculosis. J. Sens. 2020, 2020. [CrossRef]

28. Mahmoud, K.A.; Male, K.B.; Hrapovic, S.; Luong, J.H.T. Cellulose Nanocrystal/Gold Nanoparticle Composite as a Matrix for Enzyme Immobilization. ACS Appl. Mater. Interfaces 2009, 1, 1383-1386. [CrossRef]

29. Kedzior, S.A.; Dubé, M.E.; Cranston, E.D. Tailoring Cellulose Nanocrystal and Surfactant Behavior in Miniemulsion Polymerization. Macromolecules 2017, 50, 2645-2655. [CrossRef]

30. Mohamad, F.S.; Mat Zaid, M.H.; Abdullah, J.; Zawawi, R.M.; Lim, H.N.; Sulaiman, Y.; Rahman, N.A. Synthesis and Characterization of Polyaniline/Graphene Composite Nanofiber and its Application as an Electrochemical DNA Biosensor for the Detection of Mycobacterium tuberculosis. Sensors 2017, 17, 2789. [CrossRef]

31. Mohd Azmi, U.Z.; Yusof, N.A.; Kusnin, N.; Abdullah, J.; Suraiya, S.; Ong, P.S.; Ahmad Raston, N.H.; Abd Rahman, S.F.; Mohamad Fathil, M.F. Sandwich Electrochemical Immunosensor for Early Detection of Tuberculosis Based on Graphene/Polyaniline-Modified Screen-Printed Gold Electrode. Sensors 2018, 18, 3926. [CrossRef]

32. Mohd Bakhori, N.; Yusof, N.A.; Abdullah, J.; Wasoh, H.; Ab Rahman, S.K.; Abd Rahman, S.F. Surface Enhanced CdSe/ZnS QD/SiNP Electrochemical Immunosensor for the Detection of Mycobacterium tuberculosis by Combination of CFP10-ESAT6 for Better Diagnostic Specificity. Materials 2019, 13, 149. [CrossRef] [PubMed]

33. Chieng, B.W.; Lee, S.H.; Ibrahim, N.A.; Then, Y.Y.; Loo, Y.Y. Isolation and Characterization of Cellulose Nanocrystals from Oil Palm Mesocarp Fiber. Polymers 2017, 9, 355. [CrossRef]

34. Sirivat, A.; Paradee, N. Facile synthesis of gelatin-coated $\mathrm{Fe}_{3} \mathrm{O}_{4}$ nanoparticle: Effect of pH in Single-step Co-precipitation for Cancer Drug Loading. Mater. Design 2019, 181, 107942. [CrossRef]

35. Wang, H.W.; Lin, H.C.; Yeh, Y.C. Synthesis of $\mathrm{Fe}_{3} \mathrm{O}_{4}$ Nanowire Arrays Via Precipitation in Templates and Microwave Hydrothermal Process. Int. J. Appl. Ceram. Tec. 2009, 7, 33-38. [CrossRef]

36. Rashid, J.I.A.; Yusof, N.A. The strategies of DNA immobilization and hybridization detection mechanism in the construction of electrochemical DNA sensor: A review. Sens. Biosensing Res. 2017, 16, 19-31. [CrossRef]

37. Siljander, S.; Keinanen, P.; Raty, A.; Ramakrishnan, K.R.; Tuukkanen, S.; Kunnari, V.; Harlin, A.; Vuorinen, J.; Kanerva, M. Effect of Surfactant Type and Sonication Energy on the Electrical Conductivity Properties of Nanocellulose-CNT Nanocomposite Films. Int. J. Mol. Sci. 2018, 19, 1819. [CrossRef]

38. García-Miranda, F.A.; Foster, C.W.; Kelly, P.J.; Brownson, D.A.C.; Banks, C.E. Determination of the Electrochemical Area of Screen-Printed Electrochemical Sensing Platforms. Biosensors 2018, 8, 53. [CrossRef]

39. Thomas, D.; Rasheed, Z.; Jagan, J.S.; Kumar, K.G. Study of kinetic parameters and development of a voltammetric sensor for the determination of butylated hydroxyanisole (BHA) in oil samples. J. Food Sci. Technol. 2015, 52, 6719-6726. [CrossRef]

40. Seeber, R.; Zanardi, C.; Inzelt, G. The inherent coupling of charge transfer and mass transport processes: The curious electrochemical reversibility. Chem. Texts 2016, 2, 8. [CrossRef]

41. Pages, B.J.; Ang, D.L.; Wright, E.P.; Aldrich-Wright, J.R. Metal complex interactions with DNA. Dalton Trans. 2015, 44, 3505-3526. [CrossRef] 
42. Shahabadi, N.; Mohammadi, S. Synthesis Characterization and DNA Interaction Studies of a New Zn(II) Complex Containing Different Dinitrogen Aromatic Ligands. Bioinorg. Chem Appl. 2012, 2012, 571913. [CrossRef] [PubMed]

43. Venkateswarlu, S.; Himagirish Kumar, S.H.; Jyothi, N.V.V. Rapid removal of Ni (II) from aqueous solution using 3-Mercaptopropionic acid functionalized bio magnetite nanoparticles. Water Resour. Ind. 2015, 12, 1-7. [CrossRef]

Sample Availability: MTB samples are available only with permission from the ethical community of university Putra Malaysia (UPM) and Institute for Medical Research, Malaysia (IMR).

(C) 2020 by the authors. Licensee MDPI, Basel, Switzerland. This article is an open access article distributed under the terms and conditions of the Creative Commons Attribution (CC BY) license (http://creativecommons.org/licenses/by/4.0/). 